\title{
Toll-like receptor 2 and 4 genes influence susceptibility to adverse effects of traffic-related air pollution on childhood asthma
}

\author{
M Kerkhof, ${ }^{1}$ D S Postma, ${ }^{2}$ B Brunekreef, ${ }^{3,4}$ N E Reijmerink, ${ }^{2,5}$ A H Wijga, ${ }^{6}$ \\ J C de Jongste, ${ }^{7}$ U Gehring, ${ }^{3}$ G H Koppelman ${ }^{8}$
}

- Supplementary tables are published online only. To view these files please visit the journal online (http://thorax.bmj. com)

${ }^{1}$ Department of Epidemiology, University Medical Center Groningen, University of Groningen, Groningen, The Netherlands

${ }^{2}$ Department of Pulmonology, University Medical Center Groningen, University of Groningen, Groningen, The Netherlands

${ }^{3}$ Institute for Risk Assessment Sciences, Utrecht University, Utrecht, The Netherlands

${ }^{4}$ Julius Center for Health Sciences and Primary Care, University Medical Center Utrecht, The Netherlands ${ }^{5}$ Department of Pediatrics, Beatrix Children's Hospital, University Medical Center Groningen, University of Groningen, Groningen, The Netherlands

${ }^{6}$ Center for Prevention and Health Services Research, National Institute for Public Health and Environment, Bilthoven, The Netherlands 'Department of

Pediatrics/Respiratory Medicine, Erasmus University, Rotterdam, The Netherlands

${ }^{8}$ Department of Pediatric Pulmonology and Pediatric Allergology, Beatrix Children's Hospital, University Medical Center Groningen, University of Groningen, Groningen, The Netherlands

\section{Correspondence to}

Dr M Kerkhof, Department of Epidemiology, University Medical Center Groningen, P.O. Box 30.001, 9700 RB Groningen, The Netherlands; m.kerkhof@epi.umcg.nl

Received 13 May 2009 Accepted 13 May 2010

\begin{abstract}
Background Epidemiological studies have reported adverse effects of ambient air pollution on the prevalence of asthma. Laboratory studies have suggested that innate immune responses are involved. Objective A study was undertaken to determine whether the Toll-like receptor 2 and 4 genes (TLR2 and $T L R 4)$ influence the susceptibility to adverse effects of traffic-related air pollution with respect to the prevalence of childhood asthma.
\end{abstract}

Methods Haplotype tagging single nucleotide polymorphisms (SNPS) in the TLR2 $(\mathrm{n}=4)$ and TLR4 genes $(n=9)$ were genotyped in 916 children from the Prevention and Incidence of Asthma and Mite Allergy (PIAMA) birth cohort. Exposure to particulate matter $\left(\mathrm{PM}_{2.5}\right)$, soot and nitrogen dioxide $\left(\mathrm{NO}_{2}\right)$ at the birth address was estimated by land use regression models. Interactions between levels of pollutants and SNPs in relation to annual questionnaire reports of asthma diagnosis and symptoms from birth up to 8 years of age were analysed longitudinally by generalised estimating equations.

Results Two TLR2 SNPs and four TLR4 SNPs significantly modified the effect of air pollution on the prevalence of doctor-diagnosed asthma from birth up to 8 years of age. The risk of having doctor-diagnosed asthma increased with increasing $\mathrm{PM}_{2.5}$ levels in children with at least one copy of the TLR2 rs4696480 A allele (OR 2.0 (95\% Cl 1.2 to 3.1) for an interquartile range increase in exposure). Similar observations were present with the following TLR4 genotypes: rs2770150 TC (OR 2.0 (95\% Cl 1.1 to 3.6)), rs10759931 GG (OR 2.6 (95\% Cl 1.4 to 4.9$)$ ), rs6478317 GG (OR 2.2 (95\% Cl 1.2 to 4.3$)$ ), rs10759932 CT or CC (OR $2.9(95 \% \mathrm{Cl} 1.2$ to 6.9$))$ and rs1927911 TT (OR 4.4 (95\% Cl 1.7 to 11.7$)$ ).

Conclusions Variant alleles of TLR2 and TLR4 genes influence the susceptibility to adverse effects of traffic-related air pollution on childhood asthma.

\section{INTRODUCTION}

Many epidemiological studies have reported adverse effects of ambient air pollution on respiratory health, ${ }^{1}{ }^{2}$ and birth cohort studies have shown effects on the development of asthma in particular. $^{3-6}$

The mechanisms behind the adverse effects of air pollution on the lungs have not been fully elucidated. It has been established that air pollutants induce an inflammatory response that is maintained by activation of proinflammatory molecules. This may induce lung damage due to generation of reactive oxygen species. ${ }^{7}$ Furthermore, it has been suggested that air pollutant particles may act as carriers of microbes and allergens, directing their deposition to sites in the airways they would not by themselves reach due to their aerodynamic properties. $^{89}$ Thus, innate immune responses may be involved in the response to microbial components associated with particulate matter from ambient air pollution. The laboratory work of Becker et al on airway wall and bronchoalveolar cells obtained from healthy subjects suggests that Toll-like receptors (TLR) 2 and 4 on human alveolar macrophages and, preferentially, TLR2 on bronchial epithelial cells are involved in responses to pollution particles. 89 Other supportive evidence for the involvement of TLRs in the airway inflammatory response has been provided by the observation that mice previously exposed to ozone developed asthma-like reactions after inhalation of lipopolysaccharide (LPS) accompanied by mobilisation of TLR4 to the surface of inflammatory cells. ${ }^{10}$

Since there is a wide interindividual variability in responses to air pollution, ${ }^{1}$ it is plausible that genetic factors contribute to this variability. ${ }^{11}$ The majority of studies on gene-environment interactions investigated genes involved in antioxidant defences and tumour necrosis factor (TNF) $\alpha$ with respect to ozone exposure. ${ }^{12-14}$ A linkage analysis with recombinant inbred strains of mice showed TLR 4 to be a candidate gene contributing to the response to ozone-induced lung permeability and inflammation. ${ }^{15}$

There is no evidence available from epidemiological studies as to whether single nucleotide polymorphisms (SNPs) in TLRs contribute to the observed deleterious effects of air pollution on the development of asthma. We therefore studied whether polymorphisms in TLR2 and TLR 4 influence susceptibility to adverse effects of trafficrelated air pollution on the prevalence of asthma in childhood in the prospective birth cohort study Prevention and Incidence of Asthma and Mite Allergy (PIAMA)

\section{METHODS \\ Study population}

The PIAMA study consisted of two parts: a placebo controlled intervention study in which the effect of mite-impermeable mattress covers was studied and a natural history study in which no intervention took place. Details of the study design have been published previously. ${ }^{16}$ Recruitment took place in 1996-7 in three different regions of the 
Netherlands. A screening questionnaire was distributed to 10232 pregnant women visiting one of 52 prenatal clinics. Mothers reporting a history of asthma, current hay fever or allergy to pets or house dust were defined as allergic. Based on this screening, 4146 pregnant women were enrolled. All 1327 children of allergic mothers and a random sample of 663 children of non-allergic mothers were selected for a medical examination at 4 years of age. A total of 1808 children were approached for this examination, 1288 of whom participated. DNA was collected from 1046 of these children and genotypes of TLR2 and TLR4 were obtained from 1037 children. Children of nonCaucasian ethnicity were excluded from the analyses $(n=51)$. Complete data on air pollutant levels and potential confounding variables were obtained from 916 of these children.

\section{Asthma definition}

Information on respiratory health was obtained from annual questionnaires completed by the parents at the time of the child's birthday until the age of 8 years.

First, we analysed 'doctor-diagnosed asthma', defined as asthma ever diagnosed by a doctor and asthma present in the last 12 months, which was available from birth up to age 8 . Second, we used a definition of asthma based on symptoms, defined as at least one attack of wheeze or dyspnoea and/or the prescription of inhaled corticosteroids in the last 12 months. Since data on dyspnoea and inhaled steroids were not available for the first 2 years of life, this definition was used for the presence of asthma from age 2 up to age 8 .

\section{Exposure assessment}

Air pollution concentrations at the birth address of each participant were estimated by land use regression models as previously described. ${ }^{17}$ Briefly, fine particles $\left(\mathrm{PM}_{2.5}\right)$, soot and nitrogen dioxide $\left(\mathrm{NO}_{2}\right)$ were measured at 40 sites designed to capture the maximum variability in pollution from traffic sources. At each location, measurements were conducted for four 2-week periods dispersed throughout 1 year (1 March 1999 to 20 April 2000) and then adjusted for temporal trends to calculate long-term average concentrations. Geographic Information System (GIS) data on traffic, road and population density in the vicinity of each monitoring location were also collected. Regression models were developed to relate the annual average concentrations measured at the 40 monitoring sites with the GIS variables. The models explained $73 \%, 81 \%$ and $85 \%$ of the variability in the annual average concentrations for $\mathrm{PM}_{2.5}$, soot and $\mathrm{NO}_{2}$, respectively. These models were then applied to calculate ambient air pollution concentrations at the participant's home address at birth using GIS data. The long-term validity of these models is good. ${ }^{18}$

\section{SNP selection and genotyping}

Haplotype tagging SNPs were selected from the HapMap database $^{19}$ or from the Innate Immunity website $e^{20}$ based on the largest number of SNPs with a minor allele frequency $>0.1$ available in each database. Additionally, the biomedical literature available to October 2005 was screened for SNPs within the candidate genes known to have functional impact or to be associated with asthma or atopy. Genomic DNA was extracted from buccal swabs or blood using standard methods and amplified using REPLI-g UltraFast technology (Qiagen). Genotyping was performed by Competitive Allele-Specific PCR using KASPar genotyping chemistry, performed under contract by KBiosciences (Hoddesdon, Herts, UK). The quality of the genotype data was guaranteed by standards of KBiosciences and verified by comparing the genotyping results in genomic versus amplified DNA in a subset of children.

The SNPs selected for analyses are listed in table 1 and linkage disequilibrium (LD) patterns established by Haploview 4.1 are shown in figure 1.

All SNPs were analysed for Hardy-Weinberg equilibrium (HWE) using $\chi^{2}$ statistics $(p>0.01)$ in 421 children who had never had asthma symptoms or a doctor's diagnosis of asthma.

\section{Confounding variables}

The analyses were adjusted for the following potential confounding variables: sex, type of intervention (mite-impermeable mattress covers, placebo covers or no intervention), allergies of mother and father, parental education (low, intermediate or high), maternal smoking during pregnancy, exposure to smoke at home in the first year of life, duration of breastfeeding (never, 1-12 weeks, $>12$ weeks), presence of a gas stove, presence of older siblings, daycare attendance, signs of dampness in the house, presence of cats and/or dogs, type of home (single family dwelling, apartment/flat) and presence of fitted carpeting. Overall, changes in ORs due to confounder adjustment were small $(<10 \%)$.

\section{Methods of analysis}

Differences in median levels of air pollution between groups were calculated by Mann-Whitney tests and differences in proportions by $\chi^{2}$ tests. Longitudinal associations between exposure to air pollution at the birth address and yearly questionnaire reports of health outcomes at age 1-8 years were analysed by generalised estimating equations (GEE). ${ }^{21}$ A 7-dependent (5-dependent for asthma symptoms) correlation matrix was chosen to account for correlations between repeated observations in the same individual.

Interactions between exposure to air pollution and SNPs from the TLR2 and TLR4 genes were studied by including an interaction term into the model. ORs are presented for an interquartile range increase in estimated exposures $\left(11.29 \mu \mathrm{g} / \mathrm{m}^{3}\right.$ for $\mathrm{NO}_{2}, 3.44 \mu \mathrm{g} / \mathrm{m}^{3}$ for $\mathrm{PM}_{2.5}$ and $0.61 \times 10^{-5} / \mathrm{m}$ for soot) for the three genotypes separately, for SNPs with a minor allele frequency of at least $24 \%$ to maintain sufficient statistical power. Otherwise, a dominant genetic model was applied. Bestfitting genetic models (dominant, recessive or log-additive) were chosen by Akaike's information criterion.

Since half of the children of the study population $(n=462)$ moved house in the first 8 years of life, we also performed

Table 1 Characteristics of TLR2 and TLR4 single nucleotide polymorphisms (SNPs) in the study population

\begin{tabular}{lllll}
\hline Gene & SNP & Alleles* & MAF & Location \\
\hline TLR2 & rs4696480 & $\mathrm{T} \rightarrow \mathrm{A}$ & 0.47 & Intron \\
& rs1898830 & $\mathrm{A} \rightarrow \mathrm{G}$ & 0.36 & Intron \\
& rs3804099 & $\mathrm{T} \rightarrow \mathrm{C}$ & 0.45 & Exon (synonymous) \\
& rs3804100 & $\mathrm{T} \rightarrow \mathrm{C}$ & 0.07 & Exon (synonymous) \\
TLR4 & rs2770150 & $\mathrm{T} \rightarrow \mathrm{C}$ & 0.29 & Promoter \\
& rs10759931 & $\mathrm{G} \rightarrow \mathrm{A}$ & 0.41 & Promoter \\
& rs6478317 & $\mathrm{A} \rightarrow \mathrm{G}$ & 0.32 & Promoter \\
& rs10759932 & $\mathrm{T} \rightarrow \mathrm{C}$ & 0.12 & Promoter \\
& rs1927911 & $\mathrm{C} \rightarrow \mathrm{T}$ & 0.24 & Intron \\
& rs11536878 & $\mathrm{C} \rightarrow \mathrm{A}$ & 0.12 & Intron \\
& rs4986790 & $\mathrm{A} \rightarrow \mathrm{G}$ & 0.06 & Exon (Asp299Gly) \\
& rs4986791 & $\mathrm{C} \rightarrow \mathrm{T}$ & 0.06 & Exon (lle399Thr) \\
& rs11536889 & $\mathrm{G} \rightarrow \mathrm{C}$ & 0.14 & 3'UTR \\
\hline
\end{tabular}

*Major allele $<$ minor allele; MAF, minor allele frequency. 
Figure 1 Linkage disequilibrium pattern of single nucleotide polymorphisms in Toll-like receptor (TLR) genes $T L R 2$ and $T L R 4$. Values indicate $r^{2}$.

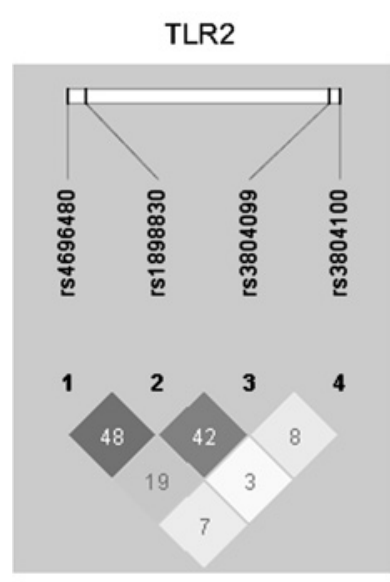

TLR4

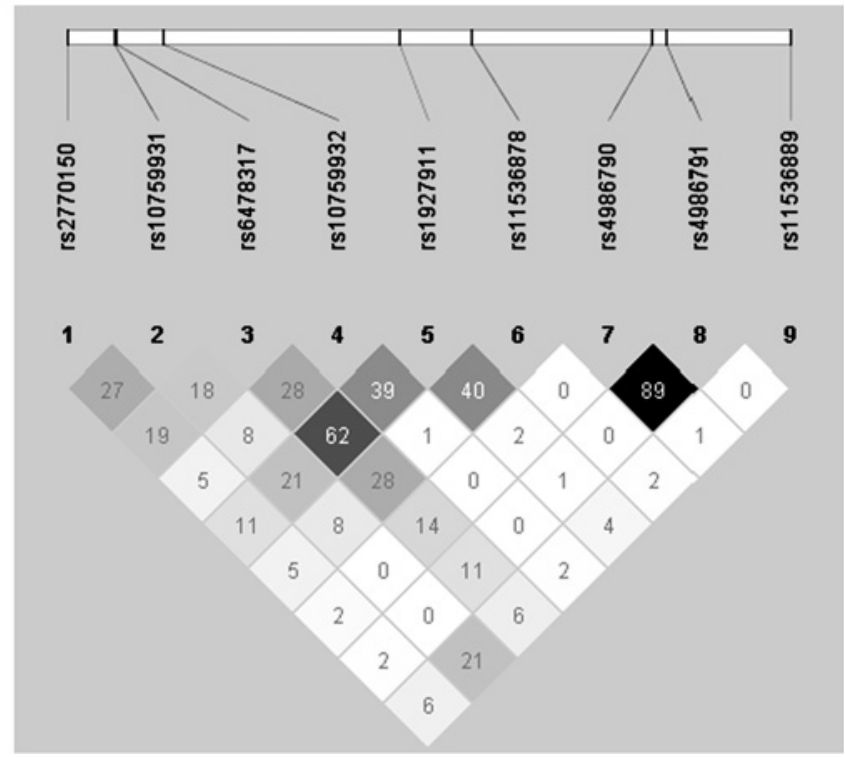

a longitudinal analysis with exclusion of these children after they had moved.

\section{RESULTS}

The prevalence of asthma symptoms decreased with increasing age in the first 8 years of life, while the prevalence of asthma diagnosed by a doctor was more constant over the ages, except for a higher prevalence in the first year of life (figure 2).

Several characteristics were different between children in the current gene-environment interaction study and children eligible for the medical examination at age 4 who did not participate (table 2).

The children who participated had parents with a higher mean education level and were less likely to live in a flat or to be exposed to cigarette smoke, a dog or dampness in the home than children who did not participate. They were also exposed to somewhat lower levels of air pollutants at their birth address, probably due to differences in participation rates for the medical examination between the regions.

The estimated annual average level of exposure to trafficrelated air pollution differed between the regions. Children born in the North of the Netherlands were exposed to lower levels of air pollutants than children from the other regions (median levels of $\mathrm{PM}_{2.5}: 14.3,18.0$ and $17.2 \mu \mathrm{g} / \mathrm{m}^{3}$, soot: $1.22,1.85$ and $1.85 \times 10^{-5} / \mathrm{m}, \mathrm{NO}_{2}$ : $15.6,26.6$ and $28.6 \mu \mathrm{g} / \mathrm{m}^{3}$ for the North, Middle and West regions, respectively).

The main associations between air pollution exposure and asthma outcomes were non-significant in the study population, but with comparable levels and direction in the adjusted ORs as in the larger total PIAMA cohort that have been presented in a previous paper ${ }^{18}$ (ie, adjusted $\mathrm{OR}$ for $3.2 \mu \mathrm{g} / \mathrm{m}^{3}$ increase in $\mathrm{PM}_{2.5} 1.33$ (95\% CI 0.94 to 1.86) for diagnosed asthma in the current study compared with 1.26 (95\% CI 1.04 to 1.51$)$ in the total cohort).

The main associations between TLR2 and TLR4 SNPs and asthma outcomes were only significant for TLR2 SNP rs4696480 which was significantly associated with doctor-diagnosed asthma (OR 0.59 (95\% CI 0.38 to 0.91 ), $\mathrm{p}=0.02$ for TA/AA vs TT) (see tables in online supplement).

\section{TLR 2}

SNPs rs4696480 and rs1898830 in the TLR2 gene significantly modified the effect of $\mathrm{PM}_{2.5}$ exposure on the prevalence of doctor-diagnosed asthma from birth up to 8 years of age (table 3). The risk of having doctor-diagnosed asthma increased with increasing $\mathrm{PM}_{2.5}$ levels only in children with at least one copy of the rs4696480 A-allele (OR 1.88 (95\% CI 1.16 to 3.06), $\mathrm{p}=0.01$ for an interquartile range increase in exposure under the best-fitting dominant genetic model). SNPs of TLR2 did not significantly interact with the level of exposure to air pollutants
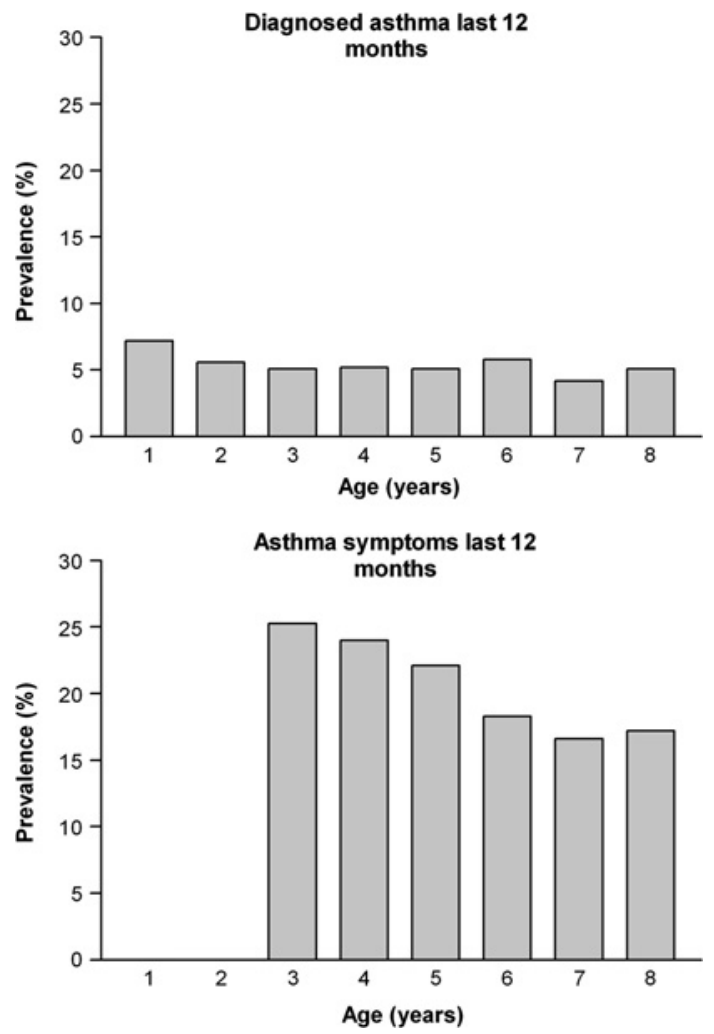

Figure 2 Prevalence of doctor-diagnosed asthma and asthma symptoms by age. 
Table 2 Characteristics of the study population and eligible children

\begin{tabular}{|c|c|c|c|}
\hline Characteristics at birth & $\begin{array}{l}\text { Study } \\
\text { population } \\
\text { ( } \mathrm{n}=916)\end{array}$ & $\begin{array}{l}\text { Total eligible } \\
\text { population } \\
\text { (n=1808) }\end{array}$ & p Value* \\
\hline Gender (\% boys) & 51.2 & 51.1 & 0.89 \\
\hline Region (\%) & & & 0.02 \\
\hline North & 32.8 & 30.6 & \\
\hline Middle & 38.3 & 37.7 & \\
\hline West & 28.9 & 31.7 & \\
\hline Study type (\%) & & & 0.02 \\
\hline Active intervention & 23.7 & 21.1 & \\
\hline Placebo intervention & 18.0 & 18.8 & \\
\hline Natural history & 58.3 & 60.1 & \\
\hline Allergic mother (\%) & 64.7 & 64.9 & 0.90 \\
\hline Allergic father (\%) & 30.7 & 31.7 & 0.37 \\
\hline Mother's education (\%) & & & $<0.001$ \\
\hline Low & 18.3 & 22.7 & \\
\hline Medium & 42.6 & 42.1 & \\
\hline High & 39.1 & 35.3 & \\
\hline Father's education (\%) & & & $<0.001$ \\
\hline Low & 20.7 & 25.6 & \\
\hline Medium & 34.3 & 34.1 & \\
\hline High & 45.0 & 40.4 & \\
\hline Mother smoking pregnancy (\%) & 9.9 & 16.2 & 0.009 \\
\hline Smoke exposure at home $(\%)$ & 18.9 & 22.1 & 0.001 \\
\hline Breast feeding duration (\%) & & & $<0.001$ \\
\hline Never & 14.3 & 20.2 & \\
\hline$<3$ months & 34.3 & 35.7 & \\
\hline$\geq 3$ months & 51.4 & 44.1 & \\
\hline Gas stove for cooking (\%) & 83.7 & 82.9 & 0.33 \\
\hline Older siblings $(\%)$ & 48.3 & 48.9 & 0.57 \\
\hline Daycare attendance first year (\%) & 24.9 & 23.8 & 0.27 \\
\hline Signs of dampness in the home (\%) & 11.5 & 13.1 & 0.03 \\
\hline Cat(s) at home (\%) & 29.8 & 29.5 & 0.79 \\
\hline Dog(s) at home $(\%)$ & 13.8 & 16.4 & 0.002 \\
\hline Type of home (\%) & & & $<0.001$ \\
\hline Single-family dwelling & 73.4 & 69.7 & \\
\hline Apartment or flat & 26.6 & 30.3 & \\
\hline Fitted carpet (\%) & 20.1 & 20.5 & 0.67 \\
\hline \multicolumn{4}{|l|}{$\begin{array}{l}\text { Estimated annual average } \\
\text { concentrations of (median, } \\
\text { interquartile range) }\end{array}$} \\
\hline $\mathrm{PM}_{2.5}\left(\mu \mathrm{g} / \mathrm{m}^{3}\right)$ & $17.2(14.7-18.1)$ & $17.3(15.0-18.2)$ & 0.04 \\
\hline Soot $(10-5 / \mathrm{m})$ & $1.77(1.30-1.91)$ & $1.78(1.35-1.92)$ & 0.01 \\
\hline Nitrogen dioxide $\left(\mu \mathrm{g} / \mathrm{m}^{3}\right)$ & $25.8(17.4-28.6)$ & $26.1(18.7-29.3)$ & 0.001 \\
\hline
\end{tabular}

${ }^{*} p$ Value for difference between study population and eligible children who did not participate.

in relation to the presence of asthma symptoms from age 2 up to 8 years of age (table 4$)$

\section{TLR4}

Four different TLR4 genotypes significantly modified the effect of exposure to air pollution on doctor-diagnosed asthma (table 5). The risk of doctor-diagnosed asthma only increased with increasing $\mathrm{PM}_{2.5}$ levels in children with the following five genotypes: rs2770150 TC (OR 2.01 (95\% CI 1.13 to 3.57)), rs10759931 GG (OR 2.61 (95\% CI 1.40 to 4.88)), rs6478317 GG (OR 2.24 (95\% CI 1.18 to 4.26)), rs10759932 CT or CC (OR 2.90 (95\% CI 1.22 to 6.91)) and rs1927911 TT (OR 4.43 (95\% CI 1.68 to 11.73$)$ ) (table 5).

Figure 3 shows how the rs10759931 genotype modified the relationship between $\mathrm{PM}_{2.5}$ exposure and the presence of doctordiagnosed asthma at age 8 for the best-fitting log-additive genetic model. At low levels of $\mathrm{PM}_{2.5}$ exposure, children with the
GG genotype of rs10759931 had a relatively low risk of asthma compared with children with the other genotypes. The risk of asthma, however, increased with increasing levels of $\mathrm{PM}_{2.5}$ in these children and at high levels of exposure the GG genotype conferred a considerably higher risk for having diagnosed asthma compared with the other genotypes (figure 3).

For asthma symptoms, only rs10759931 showed a significant interaction with air pollutant levels (table 6).

\section{Age dependency}

We have previously shown little variation in the main effects of air pollution on asthma with age. ${ }^{18}$ In the current analyses we again found no indications for age-dependent effects of air pollution on asthma. For rs10759931 the interactions with air pollution were significant at ages 1, 4, 5 and 8 years. The ORs for diagnosed asthma were all $>1$ in the group with the GG genotype and significant at ages 1, 4, 5, 6 and 8 years.

\section{Analyses in children who did not move house}

Half of the children of the study population $(n=462)$ moved during the first 8 years of life. When we excluded children from the analyses after they had moved, similar results were obtained. The interactions between rs10759931 and the level of different air pollutants in relation to diagnosed asthma remained significant with OR 2.33 (95\% CI 1.24 to 4.37) for $\mathrm{PM}_{2.5}$, OR 2.18 (95\% CI 1.25 to 3.79 ) for soot and OR 1.78 (95\% CI 1.09 to 2.90 ) for $\mathrm{NO}_{2}$ in children with the GG genotype.

\section{DISCUSSION}

In this prospective study we showed that genes of TLR2 and TLR4 influenced the susceptibility to adverse effects of trafficrelated air pollution on the development of asthma in childhood up to the age of 8 years. Adverse effects of air pollution on asthma were observed in children with specific genotypes of $T L R 2$ and TLR4. Our genetic epidemiological findings thus support previous laboratory findings suggesting involvement of these TLRs in the response to air pollution. ${ }^{8-10}$

There is emerging evidence for the role of the innate immune response in the development of asthma. Several studies have shown associations of asthma with polymorphisms in TLR and CD14 genes. $^{22}{ }^{23}$ Moreover, in recent years it has become increasingly clear that environmental exposures have to be considered when studying the effects of these important candidate genes on asthma. For the CD14 gene it has even been shown that the same genetic variants may be associated with opposite phenotypes in different environments. ${ }^{24}$ Our results provide a new example of such a complex interaction by showing that the effects of variants in TLR2 and TLR 4 genes on childhood asthma depend on the level of air pollution next to endotoxin and farming exposures as previously described. ${ }^{25} 26$ Eder et al found that children with a Tallele of TLR2-16934 (rs4696480) growing up on a farm were less likely to have a diagnosis of asthma. ${ }^{25}$ Interestingly, we found that the same SNP interacted with $\mathrm{PM}_{2.5}$ exposure (ie, the risk of a diagnosis of asthma increased with increasing $\mathrm{PM}_{2.5}$ exposure in children with an A allele only). Werner et al showed that two non-synonymous SNPs of the TLR 4 gene (rs4986790 and rs4986791) modified the effect of endotoxin exposure on asthma in adults. ${ }^{26}$ The risk of asthma increased with elevated endotoxin levels in house dust in non-carriers of the mutant alleles only. However, we could not show any interaction of these two SNPs with air pollution, possibly due to a low allele frequency in our population.

Our results suggest that microbial components are important players in the response to ambient air pollution. TLRs are the 
Table 3 Association between annual average exposure to air pollution at the birth address and doctordiagnosed asthma in the first 8 years of life stratified by different genotypes of TLR2 single nucleotide polymorphisms (SNPs)

\begin{tabular}{|c|c|c|c|c|}
\hline \multirow{2}{*}{$\frac{\text { TLR2 SNP }}{\text { rs4696480 }}$} & \multicolumn{3}{|c|}{ Adjusted $0 \mathrm{R}^{*}(95 \% \mathrm{CI})$} & \multirow{2}{*}{$\begin{array}{l}\begin{array}{l}\text { p Values } \\
\text { interaction } \dagger\end{array} \\
\text { TA/AA }\end{array}$} \\
\hline & $\mathrm{TT}$ & $\mathrm{TA}$ & AA & \\
\hline $\mathrm{PM}_{2.5}$ & $0.94(0.58$ to 1.53$)$ & $1.96(1.22 \text { to } 3.14)^{* *}$ & $1.69(0.53$ to 5.35$)$ & $0.04 / 0.36$ \\
\hline Soot & $0.97(0.63$ to 1.50$)$ & $1.63(1.06 \text { to } 2.51)^{*}$ & 1.68 (0.58 to 4.86$)$ & $0.10 / 0.35$ \\
\hline $\mathrm{NO}_{2}$ & $1.00(0.66$ to 1.51$)$ & $1.46(1.01 \text { to } 2.11)^{*}$ & 1.51 (0.59 to 3.85$)$ & $0.18 / 0.43$ \\
\hline rs1898830 & AA & $\mathrm{AG}$ & $\mathrm{GG}$ & $\mathrm{AG} / \mathrm{GG}$ \\
\hline $\mathrm{PM}_{2.5}$ & $2.24(0.98$ to 5.15$)$ & 1.44 (0.92 to 2.25$)$ & $0.72(0.33$ to 1.53$)$ & $0.36 / 0.05$ \\
\hline Soot & 1.87 (0.88 to 3.97$)$ & $1.43(0.96$ to 2.12$)$ & 0.67 (0.36 to 1.27$)$ & $0.53 / 0.04$ \\
\hline $\mathrm{NO}_{2}$ & $1.67(0.87$ to 3.21$)$ & $1.32(0.91$ to 1.92$)$ & $0.73(0.41$ to 1.29$)$ & $0.53 / 0.06$ \\
\hline rs3804099 & $\mathrm{TT}$ & $\mathrm{TC}$ & $\mathrm{CC}$ & $\mathrm{TC} / \mathrm{CC}$ \\
\hline $\mathrm{PM}_{2.5}$ & $1.06(0.64$ to 1.75$)$ & $1.40(0.87$ to 2.28$)$ & 2.16 (0.65 to 7.21$)$ & $0.42 / 0.28$ \\
\hline Soot & $1.13(0.72$ to 1.79$)$ & 1.33 (0.87 to 2.02$)$ & 1.76 (0.62 to 4.98$)$ & $0.61 / 0.44$ \\
\hline $\mathrm{NO}_{2}$ & $1.17(0.77$ to 1.76$)$ & $1.16(0.78$ to 1.72$)$ & 1.71 (0.66 to 4.46$)$ & $0.99 / 0.46$ \\
\hline rs3804100 & TT & $\mathrm{TC}$ or $\mathrm{CC}$ & & \\
\hline $\mathrm{PM}_{2.5}$ & $1.32(0.89$ to 1.96$)$ & $1.24(0.44$ to 3.46$)$ & & 0.91 \\
\hline Soot & $1.34(0.92$ to 1.93$)$ & $0.77(0.33$ to 1.81$)$ & & 0.25 \\
\hline $\mathrm{NO}_{2}$ & $1.26(0.89$ to 1.78$)$ & $0.78(0.38$ to 1.63$)$ & & 0.24 \\
\hline
\end{tabular}

gatekeepers of host immunity. They recognise molecular structures called pathogen-associated molecular patterns that are shared by numerous pathogens. TLR4 initiates signalling cascades in response to LPS present in the outer membrane of Gram-negative bacteria, while TLR2 initiates signals in response to Gram-positive bacteria, mycoplasma, yeast and spirochaetes. The explanation for the interaction of TLR genes with air pollution is that air pollutants contain small particles that may act as carriers of microbes and allergens for transport deep into the respiratory tree. ${ }^{27}$

The TLR4 SNP rs10759931 has a relatively high frequency of the A allele in the European population ( $41 \%$ in our population). The functional effect of this promoter polymorphism (-2551) on
TLR4 gene expression is unknown. Bioinformatical analysis using FASTSNP (http://fastsnp.ibms.sinica.edu.tw) predicts that rs10759931 could be a GATA2 binding site and thus may be of functional relevance. We recommend performing further functional analysis of this SNP. The TLR2 SNP rs4696480 is in LD with a GT repeat polymorphism in intron 1 of TLR2 in the Dutch population. The A allele is associated with lower GT repeat numbers. There was no correlation between these TLR2 polymorphisms and TLR2 expression on granulocytes and monocytes. However, in peripheral blood mononuclear cells, in vitro stimulation with different TLR2 agonists showed variation in the TNF $\alpha$, interleukin (IL)-12 and IL-6 response associated with the number of GT repeats. ${ }^{28}$

Table 4 Association between annual average exposure to air pollution at the birth address and asthma symptoms from age 2 up to 8 years of age, stratified by different genotypes of TLR2 single nucleotide polymorphisms (SNPs)

\begin{tabular}{|c|c|c|c|c|}
\hline \multirow{2}{*}{$\frac{\text { TLR2 SNP }}{\text { rs4696480 }}$} & \multicolumn{3}{|c|}{ Adjusted $0 \mathrm{R}^{*}(95 \% \mathrm{Cl})$} & \multirow{2}{*}{$\begin{array}{l}\begin{array}{l}\text { p Values } \\
\text { interaction }\end{array} \\
\text { TA/AA }\end{array}$} \\
\hline & $\mathrm{TT}$ & TA & AA & \\
\hline $\mathrm{PM}_{2.5}$ & $1.10(0.73$ to 1.66$)$ & $1.32(0.95$ to 1.83$)$ & 0.96 (0.53 to 1.72$)$ & $0.50 / 0.69$ \\
\hline Soot & $1.14(0.79$ to 1.65$)$ & 1.18 (0.88 to 1.57$)$ & 0.97 (0.56 to 1.69 ) & $0.90 / 0.63$ \\
\hline $\mathrm{NO}_{2}$ & 1.18 (0.84 to 1.66$)$ & 1.09 (0.83 to 1.42$)$ & 0.94 (0.57 to 1.54$)$ & $0.72 / 0.45$ \\
\hline rs1898830 & AA & $A G$ & GG & $\mathrm{AG} / \mathrm{GG}$ \\
\hline $\mathrm{PM}_{2.5}$ & 1.09 (0.70 to 1.69$)$ & $1.16(0.84$ to 1.61$)$ & $1.46(0.80$ to 2.65$)$ & $0.81 / 0.44$ \\
\hline Soot & 1.02 (0.68 to 1.53$)$ & 1.17 (0.87 to 1.58$)$ & $1.26(0.75$ to 2.10$)$ & $0.58 / 0.53$ \\
\hline $\mathrm{NO}_{2}$ & 1.01 (0.69 to 1.46$)$ & $1.11(0.85$ to 1.46$)$ & 1.20 (0.74 to 1.95$)$ & $0.67 / 0.57$ \\
\hline rs3804099 & $\mathrm{TT}$ & TC & CC & $\mathrm{TC} / \mathrm{CC}$ \\
\hline $\mathrm{PM}_{2.5}$ & $1.24(0.84$ to 1.83$)$ & 1.02 (0.74 to 1.41$)$ & 1.26 (0.62 to 2.56$)$ & $0.45 / 0.96$ \\
\hline Soot & 1.25 (0.87 to 1.79$)$ & $1.00(0.75$ to 1.33$)$ & 1.18 (0.62 to 2.25$)$ & $0.33 / 0.88$ \\
\hline $\mathrm{NO}_{2}$ & 1.19 (0.86 to 1.65$)$ & 0.96 (0.73 to 1.25$)$ & 1.14 (0.62 to 2.10$)$ & $0.30 / 0.91$ \\
\hline rs3804100 & $\mathrm{TT}$ & TC or CC & & \\
\hline $\mathrm{PM}_{2.5}$ & $1.16(0.90$ to 1.50$)$ & 0.92 (0.48 to 1.75$)$ & & 0.50 \\
\hline Soot & $1.14(0.90$ to 1.44$)$ & $0.86(0.49$ to 1.54$)$ & & 0.38 \\
\hline $\mathrm{NO}_{2}$ & 1.09 (0.88 to 1.36$)$ & 0.81 (0.49 to 1.36$)$ & & 0.29 \\
\hline
\end{tabular}

*ORs represent the factor by which the odds of asthma changes with an interquartile range increase in annual average pollutant concentration at birth address adjusted for confounders within each genotype group.

$t p$ Values of interaction represent $p$ values of the differences in ORs between the specific genotype group and the common allele homozygote group. 
Table 5 Association between annual average exposure to air pollution at the birth address and doctordiagnosed asthma in the first 8 years of life stratified by different genotypes of TLR4 single nucleotide polymorphisms (SNPs)

\begin{tabular}{|c|c|c|c|c|}
\hline TLR4 SNP & Adjusted $0 \mathrm{R}^{*}(95 \% \mathrm{Cl})$ & & & $\begin{array}{l}\text { p Values } \\
\text { interaction } \dagger\end{array}$ \\
\hline rs2770150 & TT & TC & CC & $\mathrm{TC} / \mathrm{CC}$ \\
\hline $\mathrm{PM}_{2.5}$ & $0.95(0.60$ to 1.49$)$ & $2.01(1.13 \text { to } 3.57)^{*}$ & $0.92(0.27$ to 3.11$)$ & $0.04 / 0.97$ \\
\hline Soot & $0.93(0.62$ to 1.40$)$ & $1.86(1.10 \text { to } 3.13)^{*}$ & $0.67(0.30$ to 1.50$)$ & $0.04 / 0.46$ \\
\hline $\mathrm{NO}_{2}$ & 0.87 (0.59 to 1.27$)$ & $1.79(1.11 \text { to } 2.87)^{*}$ & 0.75 (0.31 to 1.84$)$ & $0.01 / 0.76$ \\
\hline rs10759931 & GG & $\mathrm{GA}$ & AA & $\mathrm{GA} / \mathrm{AA}$ \\
\hline $\mathrm{PM}_{2.5}$ & $2.61(1.40 \text { to } 4.88)^{* *}$ & $1.17(0.68$ to 2.04$)$ & $0.63(0.29$ to 1.35$)$ & $0.06 / \mathbf{0 . 0 0 5}$ \\
\hline Soot & $2.40(1.44 \text { to } 4.02)^{* * *}$ & 1.04 (0.64 to 1.69$)$ & $0.63(0.30$ to 1.31$)$ & $0.02 / 0.004$ \\
\hline $\mathrm{NO}_{2}$ & $2.01(1.27 \text { to } 3.20)^{* *}$ & $1.09(0.71$ to 1.69$)$ & $0.59(0.30$ to 1.18$)$ & $0.06 / \mathbf{0 . 0 0 4}$ \\
\hline rs6478317 & AA & AG & $\mathrm{GG}$ & $\mathrm{AG} / \mathrm{GG}$ \\
\hline $\mathrm{PM}_{2.5}$ & 1.05 (0.65 to 1.68$)$ & 1.61 (0.84 to 3.09$)$ & $2.24(1.18 \text { to } 4.26)^{*}$ & $0.29 / 0.06$ \\
\hline Soot & $0.96(0.62$ to 1.50$)$ & 1.55 (0.87 to 2.75$)$ & $2.14(1.23 \text { to } 3.74)^{* *}$ & $0.20 / \mathbf{0 . 0 3}$ \\
\hline $\mathrm{NO}_{2}$ & 1.06 (0.70 to 1.59$)$ & $1.26(0.75$ to 2.12$)$ & $2.05(1.21 \text { to } 3.49)^{* *}$ & $0.59 / 0.04$ \\
\hline rs10759932 & $\mathrm{TT}$ & CT or CC & & \\
\hline $\mathrm{PM}_{2.5}$ & $1.23(0.82$ to 1.85$)$ & $2.90(1.22 \text { to } 6.91)^{*}$ & & 0.07 \\
\hline Soot & 1.24 (0.84 to 1.82$)$ & $2.28(1.13 \text { to } 4.63)^{*}$ & & 0.13 \\
\hline $\mathrm{NO}_{2}$ & $1.18(0.82$ to 1.69$)$ & $1.79(1.06 \text { to } 3.02)^{*}$ & & 0.17 \\
\hline rs1927911 & CC & CT & $\mathrm{TT}$ & $\mathrm{CT} / \mathrm{TT}$ \\
\hline $\mathrm{PM}_{2.5}$ & $1.02(0.65$ to 1.59$)$ & $1.60(0.80$ to 3.20$)$ & $4.43(1.68 \text { to } 11.73)^{* *}$ & $0.29 / \mathbf{0 . 0 0 7}$ \\
\hline Soot & 0.98 (0.65 to 1.48$)$ & $1.54(0.83$ to 2.86$)$ & $3.24(1.45 \text { to } 7.21)^{* *}$ & $0.23 / 0.009$ \\
\hline $\mathrm{NO}_{2}$ & $1.04(0.71$ to 1.51$)$ & 1.28 (0.73 to 2.24$)$ & $2.54(1.30 \text { to } 4.96)^{* *}$ & $0.54 / 0.02$ \\
\hline rs11536878 & CC & $\mathrm{CA}$ or $\mathrm{AA}$ & & \\
\hline $\mathrm{PM}_{2.5}$ & 1.28 (0.87 to 1.87$)$ & $1.60(0.70$ to 3.67$)$ & & 0.63 \\
\hline Soot & $1.18(0.84$ to 1.67$)$ & $1.56(0.77$ to 3.15$)$ & & 0.48 \\
\hline $\mathrm{NO}_{2}$ & $1.20(0.88$ to 1.64$)$ & 1.28 (0.66 to 2.49$)$ & & 0.86 \\
\hline rs4986790 & AA & $\mathrm{AG}$ or $\mathrm{GG}$ & & \\
\hline $\mathrm{PM}_{2.5}$ & $1.36(0.90$ to 2.06$)$ & $1.06(0.56$ to 2.02$)$ & & 0.53 \\
\hline Soot & $1.25(0.84$ to 1.85$)$ & 1.19 (0.68 to 2.09$)$ & & 0.89 \\
\hline $\mathrm{NO}_{2}$ & 1.18 (0.82 to 1.69$)$ & 1.17 (0.67 to 2.01$)$ & & 0.97 \\
\hline rs4986791 & CC & CT or TT & & \\
\hline $\mathrm{PM}_{2.5}$ & $1.37(0.90$ to 2.08$)$ & $1.10(0.53$ to 1.26$)$ & & 0.61 \\
\hline Soot & $1.28(0.87$ to 1.89$)$ & $1.24(0.65$ to 2.33$)$ & & 0.92 \\
\hline $\mathrm{NO}_{2}$ & 1.22 (0.85 to 1.74$)$ & 1.14 (0.61 to 2.13$)$ & & 0.86 \\
\hline rs11536889 & GG & $\mathrm{GC}$ or $\mathrm{CC}$ & & \\
\hline $\mathrm{PM}_{2.5}$ & $1.40(0.88$ to 2.24$)$ & $1.27(0.74$ to 2.20$)$ & & 0.79 \\
\hline Soot & 1.35 (0.88 to 2.06$)$ & $1.16(0.71$ to 1.89$)$ & & 0.64 \\
\hline $\mathrm{NO}_{2}$ & 1.26 (0.85 to 1.87$)$ & 1.17 (0.74 to 1.84$)$ & & 0.79 \\
\hline
\end{tabular}

Bold values are significant: ${ }^{*} \mathrm{p}<0.05 ;{ }^{* *} \mathrm{p}<0.01 ;{ }^{* * *} \mathrm{p}<0.001$.

${ }^{*} \mathrm{ORs}$ represent the factor by which the odds of asthma changes with an interquartile range increase in annual average pollutant concentration at birth address adjusted for confounders within each genotype group.

$t p$ Values of interaction represent $p$ values of the differences in ORs between the specific genotype group and the common allele homozygote group.

We analysed the effects of air pollution components that predominantly originate from traffic sources, including the fine fraction of particulate matter $\left(\mathrm{PM}_{2.5}\right)$. The estimated exposures for the different pollutants were highly correlated within our cohort, correlation coefficients being $0.93,0.96$ and 0.97 for the correlation between $\mathrm{NO}_{2}$ and $\mathrm{PM}_{2.5}, \mathrm{NO}_{2}$ and soot, and $\mathrm{PM}_{2.5}$ and soot, respectively. Thus, it is not possible to identify which specific pollutant is responsible for the associations.

An important strength of our study is its prospective design. ${ }^{29}$ Exposures to air pollution and many potential confounders were assessed before the onset of asthma. Our results are therefore less prone to bias. Another strength is that we tested a specific hypothesis based on previous laboratory work and found epidemiological support. Our results are therefore unlikely to be false positive.

There are also some limitations. Our study population was not completely representative of the general Dutch population of children. First, children from allergic mothers were over-represented in the subgroup with DNA owing to the design of the

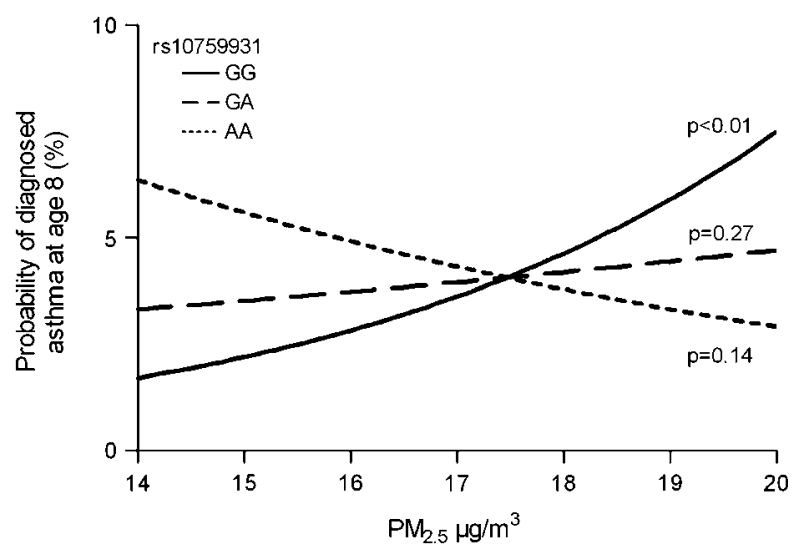

Figure 3 Mean predicted probability of having doctor-diagnosed asthma at age 8 years by estimated exposure to particulate matter $\left(\mathrm{PM}_{2.5}\right)$ stratified by single nucleotide polymorphism rs10759931 as calculated from an overall generalised estimating equation model adjusted for confounders from birth up to age 8 years. 
Table 6 Association between annual average exposure to air pollution at the birth address and asthma symptoms from age 2 up to 8 years of age stratified by different genotypes of TLR4 single nucleotide polymorphisms (SNPs)

\begin{tabular}{|c|c|c|c|c|}
\hline \multirow{2}{*}{$\frac{\text { TLR4 SNP }}{\text { rs2770150 }}$} & \multicolumn{3}{|l|}{ Adjusted OR* (95\% CI) } & \multirow{2}{*}{$\begin{array}{l}\begin{array}{l}\text { p Values } \\
\text { interaction } \dagger\end{array} \\
\mathrm{TC} / \mathrm{CC}\end{array}$} \\
\hline & TT & $\mathrm{TC}$ & CC & \\
\hline $\mathrm{PM}_{2.5}$ & 1.05 (0.76 to 1.45$)$ & 1.25 (0.85 to 1.83$)$ & $0.93(0.44$ to 1.98$)$ & $0.49 / 0.78$ \\
\hline Soot & $1.00(0.75$ to 1.34$)$ & $1.22(0.85$ to 1.74$)$ & $0.86(0.45$ to 1.62$)$ & $0.41 / 0.66$ \\
\hline $\mathrm{NO}_{2}$ & $0.99(0.76$ to 1.30$)$ & $1.15(1.82$ to 1.60$)$ & 0.85 (0.47 to 1.52$)$ & $0.51 / 0.62$ \\
\hline rs10759931 & $\mathrm{GG}$ & $\mathrm{GA}$ & AA & GA/AA \\
\hline $\mathrm{PM}_{2.5}$ & $1.61(1.07 \text { to } 2.40)^{*}$ & $1.05(0.72$ to 1.53$)$ & $0.75(0.44$ to 1.27$)$ & $0.13 / 0.02$ \\
\hline Soot & $1.56(1.09 \text { to } 2.23)^{*}$ & $0.96(0.69$ to 1.34$)$ & $0.80(0.48$ to 1.33$)$ & $0.05 / 0.04$ \\
\hline $\mathrm{NO}_{2}$ & $1.45(1.05 \text { to } 2.01)^{*}$ & 0.93 (0.68 to 1.28$)$ & $0.77(0.49$ to 1.22$)$ & $0.05 / \mathbf{0 . 0 3}$ \\
\hline rs6478317 & $\mathrm{AA}$ & $\mathrm{AG}$ & $\mathrm{GG}$ & $\mathrm{AG} / \mathrm{GG}$ \\
\hline $\mathrm{PM}_{2.5}$ & $1.00(0.72$ to 1.39$)$ & $1.23(0.83$ to 1.83$)$ & $1.57(0.76$ to 3.24$)$ & $0.42 / 0.26$ \\
\hline Soot & $0.99(0.73$ to 1.34$)$ & 1.15 (0.81 to 1.64$)$ & $1.52(0.82$ to 2.84$)$ & $0.51 / 0.22$ \\
\hline $\mathrm{NO}_{2}$ & $0.96(0.72$ to 1.28$)$ & $1.05(0.77$ to 1.44$)$ & $1.83(0.99$ to 3.39$)$ & $0.66 / 0.06$ \\
\hline rs10759932 & $\mathrm{TT}$ & $\mathrm{TC}$ or $\mathrm{CC}$ & & \\
\hline $\mathrm{PM}_{2.5}$ & $1.11(0.85$ to 1.44$)$ & $1.65(0.94$ to 2.88$)$ & & 0.20 \\
\hline Soot & $1.10(0.87$ to 1.40$)$ & $1.42(0.86$ to 2.33$)$ & & 0.36 \\
\hline $\mathrm{NO}_{2}$ & 1.08 (0.86 to 1.35$)$ & 1.20 (0.80 to 1.79$)$ & & 0.64 \\
\hline rs1927911 & $\mathrm{CC}$ & CT & TT & $\mathrm{CT} / \mathrm{TT}$ \\
\hline $\mathrm{PM}_{2.5}$ & $0.99(0.74$ to 1.34$)$ & $1.37(0.87$ to 2.16$)$ & $2.17(0.84$ to 5.62$)$ & $0.24 / 0.12$ \\
\hline Soot & $0.98(0.74$ to 1.29$)$ & 1.28 (0.85 to 1.93$)$ & $1.90(0.87$ to 4.13$)$ & $0.28 / 0.11$ \\
\hline $\mathrm{NO}_{2}$ & $0.97(0.75$ to 1.25$)$ & $1.15(0.80$ to 1.66$)$ & 2.07 (0.99 to 4.32$)$ & $0.43 / 0.06$ \\
\hline rs11536878 & $\mathrm{CC}$ & $\mathrm{CA}$ or $\mathrm{AA}$ & & \\
\hline $\mathrm{PM}_{2.5}$ & 1.11 (0.85 to 1.43 ) & 1.43 (0.81 to 2.50$)$ & & 0.42 \\
\hline Soot & $1.07(0.84$ to 1.35$)$ & $1.33(0.82$ to 2.15$)$ & & 0.43 \\
\hline $\mathrm{NO}_{2}$ & $1.01(0.81$ to 1.26$)$ & 1.35 (0.87 to 2.09$)$ & & 0.24 \\
\hline rs4986790 & $\mathrm{AA}$ & $\mathrm{AG}$ or $\mathrm{GG}$ & & \\
\hline $\mathrm{PM}_{2.5}$ & $1.16(0.89$ to 1.51$)$ & 0.87 (0.48 to 1.57$)$ & & 0.38 \\
\hline Soot & $1.10(0.87$ to 1.42$)$ & 0.88 (0.52 to 1.49$)$ & & 0.44 \\
\hline $\mathrm{NO}_{2}$ & $1.05(0.84$ to 1.32$)$ & $0.93(0.56$ to 1.54$)$ & & 0.68 \\
\hline rs4986791 & $\mathrm{CC}$ & CT or TT & & \\
\hline $\mathrm{PM}_{2.5}$ & $1.16(0.89$ to 1.51$)$ & $0.80(0.43$ to 1.50$)$ & & 0.29 \\
\hline Soot & 1.12 (0.88 to 1.43 ) & 0.82 (0.47 to 1.42$)$ & & 0.33 \\
\hline $\mathrm{NO}_{2}$ & $1.06(0.85$ to 1.33$)$ & 0.85 (0.50 to 1.44$)$ & & 0.45 \\
\hline rs11536889 & $\mathrm{GG}$ & $\mathrm{GC}$ or $\mathrm{CC}$ & & \\
\hline $\mathrm{PM}_{2.5}$ & $1.17(0.87$ to 1.57$)$ & $1.14(0.75$ to 1.72$)$ & & 0.90 \\
\hline Soot & $1.11(0.86$ to 1.45$)$ & $1.14(0.78$ to 1.68$)$ & & 0.92 \\
\hline $\mathrm{NO}_{2}$ & $1.08(0.85$ to 1.37$)$ & $1.10(0.76$ to 1.59$)$ & & 0.94 \\
\hline
\end{tabular}

PIAMA study. Second, the response to the medical examination at age 4 was related to several exposures, probably connected with socioeconomic status. We cannot fully exclude the possibility that this may have influenced the results, although we adjusted all the analyses for these exposures. Exposure assessment using land use regression models predicts outdoor concentrations of air pollutants and will not be as accurate as personal exposure measurements. Apart from the sensitivity analyses on children who did/ did not move home, we were not able to account for changes in exposure after birth. Despite these potential reasons for underestimation of the effects of air pollution on asthma, we found considerable effects in susceptible children with the GG genotype on SNP rs10759931, who constitute almost $40 \%$ of the population. This underlines the need to reduce exposure to traffic-related air pollution.

In conclusion, we found epidemiological evidence for the involvement of TLRs in the response of the airways to exposure to traffic-related air pollution. Only children with a specific genotype of SNPs in the TLR2 and TLR4 gene were susceptible to the adverse effects of air pollution on asthma in a dose-dependent way.

Acknowledgements The authors thank all the children and their parents for their cooperation, all the field workers and laboratory personnel involved for their efforts and Ada Vos for the data management.

Funding The Prevention and Incidence of Asthma and Mite Allergy (PIAMA) study is funded by the Netherlands Organisation for Health Research and Development, the Netherlands Asthma Foundation, the Netherlands Ministry of Planning, Housing and the Environment, the Netherlands Ministry of Health, Welfare and Sport and the National Institute for Public Health and the Environment.

\section{Competing interests None.}

Ethics approval The study protocol was approved by the medical ethics committees of the participating institutions.

Contributors MK contributed to the data collection and performed the data analysis and writing. NER, AHW and UG contributed to the epidemiological data collection and commented on the draught. DSP, BB, GHK and JCdJ contributed to the design of the PIAMA study and commented on the draft. All authors saw and approved the final version of the manuscript.

Provenance and peer review Not commissioned; externally peer reviewed. 


\section{REFERENCES}

1. Brunekreef B, Holgate ST. Air pollution and health. Lancet 2002;360:1233-42.

2. Trasande $\mathbf{L}$, Thurston $\mathrm{G}$. The role of air pollution in asthma and other pediatric morbidities. J Allergy Clin Immunol 2005;115:689-99.

3. Morgenstern V, Zutavern A, Cyrys J, et al. Respiratory health and individual estimated exposure to traffic-related air pollutants in a cohort of young children. Occup Environ Med 2007;64:8-16.

4. Nordling E, Berglind N, Melen E, et al. Traffic-related air pollution and childhood respiratory symptoms, function and allergies. Epidemiology 2008;19:401-8.

5. Brauer $\mathbf{M}$, Hoek $G$, van Vliet $P$, et al. Air pollution from traffic and the development of respiratory infections and asthmatic and allergic symptoms in children. $A m \mathrm{~J}$ Respir Crit Care Med 2002;166:1092-8.

6. Brauer M, Hoek G, Smit HA, et al. Air pollution and development of asthma, allergy and infections in a birth cohort. Eur Respir J 2007;29:879-88.

7. MacNee W. Oxidative stress and lung inflammation in airways disease. Eur $J$ Pharmacol 2001;429:195-207.

8. Becker S, Fenton MJ, Soukup JM. Involvement of microbial components and tolllike receptors 2 and 4 in cytokine responses to air pollution particles. Am J Respir Cell Mol Biol 2002;27:611-18.

9. Becker S, Dailey L, Soukup JM, et al. TLR-2 is involved in airway epithelial cell response to air pollution particles. Toxicol Appl Pharmacol 2005;203:45-52.

10. Hollingsworth JW, Maruoka S, Li Z, et al. Ambient ozone primes pulmonary innate immunity in mice. J Immunol 2007;179:4367-75.

11. Backus-Hazzard GS, Howden R, Kleeberger SR. Genetic susceptibility to ozoneinduced lung inflammation in animal models of asthma. Curr Opin Allergy Clin Immunol 2004;4:349-53.

12. Yang IA, Fong KM, Zimmerman PV, et al. Genetic susceptibility to the respiratory effects of air pollution. Thorax 2008;63:555-63

13. Von Mutius E. Gene-environment interactions in asthma. J Allergy Clin Immunol 2009;123:3-11.

14. Islam T, Berhane K, McConnell R, et al. Glutathione-S-transferase (GST) P1, GSTM1, exercise, ozone and asthma incidence in school children. Thorax 2009;64:197-202.

15. Kleeberger S, Reddy S, Zhang L, et al. Genetic susceptibility to ozone-induced lung hyperpermeability. Role of Toll-like receptor 4. Am J Respir Cell Mol Biol 2000;22:620-7.
16. Brunekreef B, Smit HA, de Jongste JC, et al. The Prevention and Incidence of Asthma and Mite Allergy (PIAMA) birth cohort study: design and first results. Pediatr Allergy Immunol 2002;13:55-60.

17. Brauer $\mathbf{M}$, Hoek G, van VP, et al. Estimating long-term average particulate air pollution concentrations: application of traffic indicators and geographic information systems. Epidemiology 2003;14:228-39.

18. Gehring U, Wijga A, Brauer M, et al. Traffic-related air pollution and the development of asthma and allergies during the first 8 years of life. Am J Respir Crit Care Med 2009;181:596-603

19. The International HapMap Consortium. A haplotype map of the human genome Nature 2005;437:1299-320.

20. Lazarus R, Vercelli D, Palmer LJ, et al. Single nucleotide polymorphisms in innate immunity genes: abundant variation and potential role in complex human disease. Immunol Rev 2002;190:9-25.

21. Diggle P, Liang K, Zeger SL. Analysis of longitudinal data. Oxford: Clarendon Press, 1994.

22. Yang IA, Fong KM, Holgate ST, et al. The role of Toll-like receptors and related receptors of the innate immune system in asthma. Curr Opin Allergy Clin Immunol 2006;6:23-8.

23. Smit L, Siroux V, Bouzigon E, et al. CD14 and Toll-like receptor gene polymorphisms, country living, and asthma in adults. Am J Respir Crit Care Med 2008;179:363-8.

24. Vercelli D. Genetics, epigenetics, and the environment: switching, buffering, releasing. J Allergy Clin Immunol 2004;113:381-6.

25. Eder W, Klimecki W, Yu L, et al. Toll-like receptor 2 as a major gene for asthma in children of European farmers. J Allergy Clin Immunol 2004;113:482-8.

26. Werner M, Topp R, Wimmer K, et al. TLR4 gene variants modify endotoxin effects on asthma. J Allergy Clin Immunol 2003;112:323-30.

27. Ormstad H. Suspended particulate matter in indoor air: adjuvants and allergen carriers. Toxicology 2000;152:53-68.

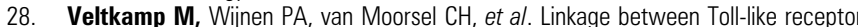
(TLR) 2 promoter and intron polymorphisms: functional effects and relevance to sarcoidosis. Clin Exp Immunol 2007;149:453-62

29. Koppelman GH. Gene by environment interaction in asthma. Curr Allergy Asthma Rep 2006;6:103-11. 